\title{
Effect of Foliar Feeding of Potash on Tree Growth Characters of Peach Cultivar Shan-e-Punjab
}

\author{
Lochan Kaushik $^{1}$, Ashish Gupta ${ }^{1}$, Devi Singh ${ }^{2}$, Prashant Kaushik ${ }^{3 *}$, \\ Devender Chahal ${ }^{4}$, Ritu Mittal ${ }^{2}$ and Hari Kesh ${ }^{5}$ \\ ${ }^{1}$ Department of Horticulture, ${ }^{5}$ Department of Genetics and Plant Breeding, Chaudhary \\ Charan Singh Haryana Agricultural University, Hisar, Haryana, India \\ ${ }^{2}$ Department of Chemistry, National Institute of Technology, Kurukshetra, Haryana, India \\ ${ }^{3}$ Instituto de Conservación y Mejora de la Agrodiversidad Valenciana, Universitat Politècnica \\ de València, 46022 Valencia, Spain \\ ${ }^{4}$ Krishi Vigyan Kendra, Ambala, Haryana, India \\ *Corresponding author
}

\section{A B S T R A C T}

\begin{tabular}{|c|c|}
\hline Keywords & $\begin{array}{l}\text { The current investigation was carried out the Department of Horticulture, CCS Haryana } \\
\text { Agricultural Faculty, Campus Kaul, Hisar, during 2014-15. The experiment was performed }\end{array}$ \\
\hline $\begin{array}{l}\text { Pruning, Potash, } \\
\text { Spray, Peach }\end{array}$ & $\begin{array}{l}\text { on } 8 \text { years old forests in Randomized Block Design with } 3 \text { replications. The treatment } \\
\text { include } 4 \text { pruning intensities [i.e., unpruned (control), light pruning ( } 20 \% \text { removal of the }\end{array}$ \\
\hline Article Info & ar spray (i.e., $0.5 \%$, water spray, 1.0 \\
\hline $\begin{array}{l}\text { Accepted: } \\
17 \text { October } 2020 \\
\text { Available Online: } \\
10 \text { November } 2020\end{array}$ & $\begin{array}{l}\text { intensity) was found better in respect of tree growth parameters. In admiration of potas } \\
\text { spray, } 1.0 \text { per dollar spray of K2SO } 4 \text { was observed outstanding with respect to tre } \\
\text { volume, tree spread, and tree height. Overall, the interaction of pruning intensity and als } \\
\text { potash levels was observed non-significant in the majority of the variables. }\end{array}$ \\
\hline
\end{tabular}

\section{Introduction}

Peach (Prunus persica) is a temperate stone fruit of family Rosaceae. Shan-e- Punjab is a popular peach cultivar from India. Along with its table use, this cultivar has also been found perfect for canning (Bal, 2006).With the help of pruning excessive fruiting is avoided, raises fruit size and also will help with mild penetration to the interior of the tree canopy, which increases new fruit colourations (Mika, 1986). Pruning works to bring about ample airflow through the whole berry tree, which helps in preventing typical tree ailments. Pruning also affects berry external and inner quality characteristics such as colour development, general soluble solid/acidity balance etc. (Lord and Greene, 1982). In peach, the appropriate pruning is vitally important in regulating the tree vigour, fruit quality and productivity potential.

Each improvement that has generated has to be pruned, or else the tree continues adding blank timber season after season. Consequently, a judicious pruning is of 
supreme significance in regulating the shoot growth along with fresh fruit yield of peach, that's pushed through the cultivar, location as well as prevailing agroclimatic condition (Satya and Nautiyal, 1994). Deficiency of virtually any among these nutrients is competent to cause problems with productions, vegetative development and also fresh fruit quality or perhaps possibly tree health (Desmond et al., 2010). The positive effect of foliar application of nourishment is dependant on the simple fact that the nutrients reach directly to leaves that include the sites of the metabolic procedure (Yadav, 2013).

Potassium occurs in younger leaves, root tips and meristematic tissues. It is required in cellular division, synthesis and translocation of carbohydrates and synthesis of protein in meristematic tissues. Carbohydrate metabolism plus storage could additionally be controlled by potassium. The colour is enhanced by it, flavour and size of fresh fruit (Bangerth et al., 1999). Fruit excess weight along with yield of peach upgraded with the increasing pace of $\mathrm{K}$ method (Awasthi et al., 1990). Therefore, here we studied the effect of foliar feeding of potash on tree growth characters of peach cultivar Shan-e-Punjab.

\section{Materials and Methods}

\section{Experimental Setup}

The present exploration was performed on peach trees in the experimental orchard, university or college of agriculture, Kaul, CCS Haryana Agricultural Faculty, Hisar. The peach trees have been belonging to type Shan-e-Punjab. Solutions foliar spray of Potassium sulphate (2nd fortnight of March)

a) 0.5 per dollar squirt of Potassium sulphate b) one per cent squirt of Potassium sulphate c) 1.5 per cent spray of Potassium sulphate d) Control (water spray)

\section{Traits}

Tree height (m) was assessed from bottom to the pinnacle in meters. Whereas tree spread (m) of the tree was assessed in both of the directions. Total above ground tree volume (m3) of the every experimental tree was estimated from level and also spread measurements based on the formulae provided by Westwood (1978). Annual Shoot length (m) was measured using the four marked branches, one on each side of the tree, five healthy shoots which produced flower buds were tagged. The length of all the tagged shoots was measured in meter with the help of a measuring tape. Fruit set (\%) was also determined based on the method of by Westwood (1978).

\section{Results and Discussion}

\section{Tree height (m)}

The data presented in Table 1 shows that pruning levels significantly influenced the tree height. The minimum tree height was recorded with 60 per cent pruning intensity $(4.91 \mathrm{~m})$, which was statistically at par with 40 per cent $(5.14 \mathrm{~m})$ and followed by 20 per cent $(5.27 \mathrm{~m})$ pruning intensity and the maximum tree height was observed in unpruned trees $(5.51 \mathrm{~m})$.

Potash spray significantly promoted the tree height. The maximum tree height $(5.43 \mathrm{~m})$ was noted with the foliar spray of 1.0 per cent $\mathrm{K}_{2} \mathrm{SO}_{4}$, which was statistically at par with application of 1.5 per cent $\mathrm{K}_{2} \mathrm{SO}_{4}(5.29 \mathrm{~m})$ and followed by 0.5 per cent $\mathrm{K}_{2} \mathrm{SO}_{4}(5.13 \mathrm{~m})$, while the minimum tree height $(4.97 \mathrm{~m})$ in control plants with water spray.

The interaction effect of pruning and potash spray was found non-significant in respect to plant height. 
Table.1 Effect of pruning intensity and foliar application of potash on tree height (m)

\begin{tabular}{|l|c|c|c|c|c|}
\hline \multirow{2}{*}{ Pruning levels } & \multicolumn{5}{|c|}{ Potash concentration (\%) } \\
\cline { 2 - 6 } & Water spray & 0.5 & 1 & 1.5 & Mean \\
\hline Control (no pruning) & 5.23 & 5.40 & 5.80 & 5.60 & 5.51 \\
\hline Light pruning (20\%) & 4.97 & 5.20 & 5.47 & 5.43 & 5.27 \\
\hline Medium pruning (40\%) & 4.93 & 5.03 & 5.37 & 5.23 & 5.14 \\
\hline Heavy pruning (60\%) & 4.73 & 4.90 & 5.10 & 4.90 & 4.91 \\
\hline Mean & 4.97 & 5.13 & 5.43 & 5.29 & \\
\hline CD at 5\% & \multicolumn{2}{|c|}{$\mathrm{P}=0.28$} & & $\mathrm{~K}=0.28$ & $\mathrm{P} \times \mathrm{K}=\mathrm{NS}$ \\
\hline
\end{tabular}

Table.2 Effect of pruning intensity and foliar application of potash on tree spread (m)

\begin{tabular}{|l|c|c|c|c|c|}
\hline \multirow{2}{*}{ Pruning levels } & \multicolumn{5}{|c|}{ Potash concentration (\%) } \\
\cline { 2 - 6 } & Water spray & 0.5 & 1 & 1.5 & Mean \\
\hline Control (no pruning) & 5.90 & 6.13 & 6.53 & 6.30 & 6.22 \\
\hline Light pruning (20\%) & 5.50 & 5.83 & 6.07 & 5.87 & 5.82 \\
\hline Medium pruning (40\%) & 5.40 & 5.67 & 5.93 & 5.90 & 5.73 \\
\hline Heavy pruning (60\%) & 5.23 & 5.40 & 5.60 & 5.57 & 5.45 \\
\hline Mean & 5.51 & 5.76 & 6.03 & 5.91 & \\
\hline CD at 5\% & \multicolumn{2}{|c|}{$\mathrm{P}=0.44$} & & $\mathrm{~K}=$ & \multicolumn{2}{|c|}{$\mathrm{P} \times \mathrm{K}=\mathrm{NS}$} \\
& & & $\mathrm{NS}$ & & \\
\hline
\end{tabular}

Table.3 Effect of pruning intensity and foliar application of potash on tree volume $\left(\mathrm{m}^{3}\right)$

\begin{tabular}{|l|c|c|c|c|c|}
\hline \multirow{2}{*}{ Pruning levels } & \multicolumn{5}{|c|}{ Potash concentration (\%) } \\
\cline { 2 - 6 } & Water spray & 0.5 & 1 & 1.5 & Mean \\
\hline Control (no pruning) & 94.91 & 106.66 & 130.67 & 122.00 & 113.56 \\
\hline Light pruning (20\%) & 83.19 & 92.77 & 105.29 & 98.72 & 94.99 \\
\hline Medium pruning (40\%) & 76.33 & 84.62 & 98.73 & 98.67 & 89.47 \\
\hline Heavy pruning (60\%) & 67.71 & 75.45 & 83.72 & 78.17 & 76.31 \\
\hline Mean & 80.54 & 89.87 & 104.64 & 99.29 & \\
\hline CD at 5\% & $\mathrm{P}=5.60$ & $\mathrm{~K}=5.60$ & \multicolumn{2}{c|}{$\mathrm{P} \times \mathrm{K}=\mathrm{NS}$} \\
\hline
\end{tabular}

Table.4 Effect of pruning intensity and foliar application of potash on annual shoot length (m)

\begin{tabular}{|l|c|c|c|c|c|}
\hline \multirow{2}{*}{ Pruning levels } & \multicolumn{5}{|c|}{ Potash concentration (\%) } \\
\cline { 2 - 6 } & Water spray & 0.5 & 1 & 1.5 & Mean \\
\hline Control (no pruning) & 0.14 & 0.20 & 0.21 & 0.22 & 0.19 \\
\hline Light pruning (20\%) & 0.22 & 0.28 & 0.45 & 0.52 & 0.37 \\
\hline Medium pruning (40\%) & 0.49 & 0.59 & 0.68 & 0.89 & 0.66 \\
\hline Heavy pruning (60\%) & 0.75 & 0.95 & 0.98 & 1.08 & 0.94 \\
\hline Mean & 0.40 & 0.50 & 0.58 & 0.69 & \\
\hline CD at 5\% & $\mathrm{P}=0.10$ & & $\mathrm{~K}=0.10$ & $\mathrm{P} \times \mathrm{K}=\mathrm{NS}$ \\
\hline
\end{tabular}


Table.5 Effect of pruning intensity and foliar application of potash on fruit set (\%)

\begin{tabular}{|l|c|c|c|c|c|}
\hline \multirow{2}{*}{ Pruning levels } & \multicolumn{5}{|c|}{ Potash concentration (\%) } \\
\cline { 2 - 6 } & Water spray & 0.5 & 1 & 1.5 & Mean \\
\hline Control (no pruning) & 85.00 & 84.33 & 82.33 & 81.33 & 83.25 \\
\hline Light pruning (20\%) & 83.67 & 84.00 & 80.33 & 79.00 & 81.75 \\
\hline Medium pruning (40\%) & 82.00 & 83.67 & 77.67 & 74.67 & 79.50 \\
\hline Heavy pruning (60\%) & 80.33 & 81.00 & 77.33 & 74.67 & 78.33 \\
\hline Mean & 82.75 & 83.25 & 79.42 & 77.42 & \\
\hline CD at 5\% & \multicolumn{2}{|c|}{$\mathrm{P}=\mathrm{NS}$} & $\mathrm{K}=\mathrm{NS}$ & \multicolumn{2}{|c|}{$\mathrm{P} \times \mathrm{K}=\mathrm{NS}$} \\
\hline
\end{tabular}

\section{Tree spread (m)}

The data presented in Table 2 reveals that pruning levels significantly influenced the plant spread. The maximum plant spread $(6.22 \mathrm{~m})$ was recorded with unpruned plants, while the minimum plant spread $(5.45 \mathrm{~m})$ was recorded with pruning at 60 per cent pruning intensity, which was statistically at par with 40 per cent $(5.73 \mathrm{~m})$ and 20 per cent $(5.82 \mathrm{~m})$ pruning intensity. In case of potash spray, different concentration of potash did not significantly influence plant spread of peach.

The interaction effect of pruning and potash spray was also found non-significant in respect of plant spread.

\section{Tree volume $\left(\mathrm{m}^{3}\right)$}

The data presented in Table 3 reveals that different pruning levels had significant effect on tree volume. The minimum tree volume was noted with pruning at 60 per cent $\left(76.31 \mathrm{~m}^{3}\right)$, which was followed by 40 per cent $\left(89.47 \mathrm{~m}^{3}\right)$ and 20 per cent $\left(94.99 \mathrm{~m}^{3}\right)$ pruning intensity. The maximum tree volume (113.56 $\mathrm{m}^{3}$ ) was recorded in unpruned trees.

In case of potash spray, the maximum tree volume $\left(104.64 \mathrm{~m}^{3}\right)$ was noted with foliar spray of 1.0 per cent $\mathrm{K}_{2} \mathrm{SO}_{4}$, which was statistically at par with spray of 1.5 per cent $\mathrm{K}_{2} \mathrm{SO}_{4}\left(99.29 \mathrm{~m}^{3}\right)$ and followed by 0.5 per cent $\mathrm{K}_{2} \mathrm{SO}_{4}\left(89.87 \mathrm{~m}^{3}\right)$, while the minimum tree volume was recorded in plants with water spray $\left(80.54 \mathrm{~m}^{3}\right)$. The interaction effect of pruning and potash spray was found nonsignificant in respect of tree volume.

\section{Annual shoots length (m)}

Perusal of data in Table 4 indicated that pruning levels had significant influence on the annual shoot length. The maximum annual shoot length $(0.94 \mathrm{~m})$ was recorded with 60 per cent pruning intensity, which was followed by 40 per cent $(0.67 \mathrm{~m})$ and 20 per cent $(0.37 \mathrm{~m})$ pruning intensity and the minimum $(0.19 \mathrm{~m})$ in unpruned trees.

In case of chemical spray, annual shoot length significantly influenced by different concentration of potash spray. The maximum annual shoot length $(0.69 \mathrm{~m})$ was noted with the foliar spray of 1.5 per cent $\mathrm{K}_{2} \mathrm{SO}_{4}$, which was followed by application of 1.0 per cent $\mathrm{K}_{2} \mathrm{SO}_{4}(0.58 \mathrm{~m})$ and 0.50 per cent $\mathrm{K}_{2} \mathrm{SO}_{4}$ $(0.50 \mathrm{~m})$ and the minimum annual shoot length in plants with water spray $(0.40 \mathrm{~m})$.

The interaction effect of pruning levels and potash spray on annual shoot length was found non-significant.

\section{Fruit set (\%)}

The data presented in Table 5 reveals that pruning intensity and different concentration of potash had non-significant effect on fruit 
set under study. However, maximum fruit set was observed in unprunned tree with water spray followed by light pruning intensity at 0.5 per cent potassium spray. Minimum fruit set was recorded under medium and heavy pruning intensity at 1.5 per cent potassium spray.

Kanwar and Nijjar (1983) assessed the effect of different pruning and fertilizer treatments on development, yield and quality of peach cv. Flordasun and also found that severe pruning created a great deal more development than moderate and light pruning with respect to cumulative circumference along with the shoot length. Awasthi and Singh (1990) observed boost, which is substantial within the shoot advancement of peach with extensive pruning. Thakur (1993) discovered that light pruning additionally was determined to shoot boosting along with trunk girth as than severe pruning in different cultivars of peach. Daulta and Singh (1986) investigated the result of the intensity of pruning on yield and quality of peach cv. Sharbati. The outcomes proposed that fresh fruit mass, volume, size, stone weight, and pulp stone ratio advanced substantially by the pruning treatments over command. Lemus and Valenzuela (1986) found the berry diameter was biggest with severe pruning in nectarine peach woodlands. Francisconi et al., (1996) discovered in five-year-old peach trees that removal of more than percent of shoots significantly lowered the normal fruit weight. Mahajan and Dhillon (2002) observed high fruit size concerning length was authorized with 50 per dollar pruning, and this was at par with 70.5 per cent level of pruning during both of the years. Nevertheless, the top fresh fruit diameter (4.96 along with $5.16 \mathrm{~cm}$ ) was found with 705 per cent pruning intensity right followed by 50 per cent pruning. Daulta and Singh (1986) discovered that ripening of fresh fruit was enhanced by seven times in gravely pruned answers in comparison to control. Kanwar and Nijjar (1983) determinad that lightly pruned trees provided appreciably higher cumulative yield than primary and moderate pruned forests. Daulta and Singh (1986) investigated the number of fruits and yield per plant diminished with the improved seriousness of pruning. Kuden and Kaska (1995) discovered that yield was found to be standard with summers + wintertime pruning than unpruned command forests of Priana and Beliana apricot cultivars. Similarly, Mahajan and Dhillon (2002) discovered that 50 plus 70 5 per cent pruning intensities are found showing significantly reduced yields in peach cV.

Nevertheless, substantially greater fruit yield was acquired in pruned plants which were at par with 205 per cent pruning quantity. Kaith et al., (2011) evidenced that fresh fruit yield was decreased due to much much more vegetative growth. Additionally, he observed maximum yield in woodlands pruned in October with 50 per dollar shoot retention. Thakur and Rana (2014) concluded that there is a significant improvement of berry yield and quality in nectarine through pruning.

\section{References}

Awasthi, R.P. and Singh, N.P. (1990). Effect of NPK fertilization in relation to pruning on growth, yield and fruit quality of peach cv. Flordasun. Research and Development Reporter, 7(1-2): 26-31.

Bal, J.S. (2006). Fruit growing. $2^{\text {nd }}$ Revised Edition. Kalyani Publishers, New Delhi.

Bangerth, F. (1999). Second discussion meeting on bitter pit in apple. Acta Horticulturae, 45: 53-52.

Daulta, B.S. and Singh, D. (1986). Effect of severity of pruning on yield and quality of peach cv. Sharbati. Indian Journal of Horticulture Sciences, 43(3/4): 180-183.

Desmond, R., Bassi, L. and Bassi, D. (2010). The peach.Botany, production and uses. Printed and bound in the UK by Biddles, 
King's Lynn.

Francisconi, A.H.D., Barradas, C.I.N. and Marodin, G.A.B. (1996). Effect of summer pruning on fruit quality and yield of peach cv. Marlitrees. Pesquisa Agropecuaria Brasileria, 31(1):51-54.

fruit development in 'Shimizuhakuto' peach. Scientific Reports of the Faculty of Agriculture Okayama University, 91: 49-54.

Kaith, N.S., Sharma, U., Sharma, D.D. and Mehta, D.K. (2011). Effect of different pruning intensities on growth, yield and leaf nutrients status of Starking delicious apple in hilly region of Himachal Pradesh. Journal of Farm Sciences, 1(1):37-42.

Kanwar, J.S. and Nijjar, G.S. (1983). Effect of different pruning and fertilizer treatment on growth, yield and quality of peach (Prunus persica B.) cv. Flordasun. Indian Journal of Horticulture, 40: 4854.

Kuden, A. and Kaska, N. (1995). Effects of winter and summer pruning on the yield and fruit quality of Priana and Beliana apricot cultivars. Acta Horticulturae, 384: 455-458.

Lemus, S. and Valenzuela, B.J. (1986). Growth and yield of high density peaches trained with a central leader and Subjected to two pruning intensities. Agricultura Technica, 46(3): 361-364.

Lord, W.J. and Greene, D.W. (1982). Effect of dormant pruning, summer pruning, scoring and growth regulators on growth, yield and fruit quality of
'Delicious' and 'Cortland' apple trees. Journal of American Society of Horticulture Sciences, 108(4): 590-595.

Mahajan, B.V.C. and Dhillon, B.S. (2002). Effect of pruning intensities on the fruit size, yield and quality of peach cv. Shani-Punjab. Agriculture Science Digest, 22(4): 281-282.

Mika, A. (1986). Physiological responses of fruit trees to pruning. Horticulture Review, 8: 337-367.

Satya, P. and Nautiyal, M.C. (1994). Response of severity of pruning on fruiting and quality of 'Early White Giant' peach. Haryana Journal of Horticultural Science, 23(4): 263-268.

Thakur, N. and Rana, V.S. (2014). Influence of pruning intensity on yield and quality of nectarine peach. Journal of Horticulture Sciences, 9(1):23-26.

Thakur, S.S. (1993). Optimization of fruit bearing shoots in July Elberta peach trees. M.Sc. Thseis, Dr Y. S. Parmar University of Horticulture and Forestry, Nauni, Solan, India.

Westwood, M.N., Raimer, F.C. and Quakenbush, (1963). Long-term yield as related to ultimate tree size of three pear varieties grown on rootstock of five Pyrus spp.Proceedings of American Society of Horticulture,82: 103-108.

Yadav, D. (2013). Effect of foliar spray of different sources of potassium on quality of ber (Zizyphus mauritiana Lam.) cv. Banarasi Karaka. M.Sc. Thesis. Banaras Hindu University, Varanasi, India. 55.w

\section{How to cite this article:}

Lochan Kaushik, Ashish Gupta, Devi Singh, Prashant Kaushik, Devender Chahal, Ritu Mittal and Hari Kesh. 2020. Effect of Foliar Feeding of Potash on Tree Growth Characters of Peach Cultivar Shan-e-Punjab. Int.J.Curr.Microbiol.App.Sci. 9(11): 2452-2457. doi: https://doi.org/10.20546/ijcmas.2020.911.295 